\author{
K.A. Akylbekov \\ Institute of Natural Science and Geography, Abai KazNPU, Kazakhstan, Almaty \\ e-mail: Yes171@bk.ru

\section{INTERNATIONAL PERCEPTION ON STUDENT EFFICIENCY IN KAZAKHSTAN'S EDUCATIONAL SYSTEM}

The aim of this paper's background is to show how Kazakhstan's educational system has changed over the last 30 years of independence, demonstrating modern transformative processes. We also defined the goal of establishing the educational level as part of a competence-based approach. Reference analysis, questioning, and experimental work were used as methods. The following are the outcomes: Education quality problems have been revealed, according to the results of a review of Kazakhstan's state system of vocational education. At this stage of the educational system's development, it is clear that the concept of learning outcomes in terms of the commitment to competence is critical. The Republic of Kazakhstan's recommendations on education quality assurance are made in the context of a competence-based approach. The paper's innovation is that accuracy issues are considered in the context of VET (vocational education and training) and higher education, and each method's good experience is recommended to be included.

As part of the research, a survey of students was conducted on the basis of the Abai KazNPU. 100 respondents took part in the survey. The poll showed that $88 \%$ of respondents consider the training system insufficiently consistent with modern standards.

All of these issues can be resolved by strengthening the National Qualifications Network in accordance with the principles of the European Qualifications Network.

Key words: competences, learning outcomes, technical education, National Qualifications Network.

\author{
Қ.А. Ақылбеков \\ Абай атындағы ҚазҰПУ, Жаратылыстану және география институты, Қазақстан, Алматы қ. \\ e-mail: Yes171@bk.ru \\ Қазақстанның білім беру жүйесіндегі студенттердің \\ тиімдікігі туралы хамықаралық түсінік
}

Бұл мақаланың мақсаты - тәуелсіздіктің 30 жылында қазіргі білім беру жүйесінің қазіргі заманғы трансформациялық процестерді көрсете отырып қалай өзгергендігін көрсету. Сондай-ақ, құзыреттілік тәсіл шеңберінде білім деңгейін орнатудың мақсаттары айқындалды. Әдіс ретінде анықтамалық талдау, сауалнама және эксперименттік жұмыс қолданы^ды. Келесі нәтижелер анықта^ды: Қазақстандағы мемлекеттік кәсіптік білім беру жүйесін қарау нәтижелері бойынша білім сапасына қатысты проблемалар анықталды. Білім беру жүйесін дамытудың осы кезеңінде құзыреттілікке бейімделу тұрғысынан оқыту нәтижелері тұжырымдамасы өте маңызды екені анық. Білім беру сапасын қамтамасыз ету бойынша Қазақстан Республикасының ұсыныстары құзыреттілікке негізделген тұжырымдамада бекілген. Мақаланың жаңалығы - бұл ТжКБ және жоғары білім беру жағдайындағы дәлдік мәселелерін шешуде және әр әдістің оң тәжірибелерін қосу ұсынылады.

Зерттеу аясында Абай атындағы ҚазҰПУ негізінде студенттерге сауалнама жүргізілді. Сауалнамаға 100 респондент қатысты. Сауалнама көрсеткендей, респонденттерАің 88\%-ы оқыту жүйесін заманауи стандарттарға сәйкес емес деп санайды.

Барлық мәселелерді Ұлттық біліктілік желісін Еуропалық біліктілік желісінің қағидаттарына сәйкес күшейту арқылы шешуге болады.

Түйін сөздер: құзыреттілік, оқыту нәтижелері, техникалық білім, Ұлттық біліктілік желісі. 


\author{
К.А. Акылбеков \\ Институт естествознания и географии, КазНПУ им. Абая? Казахстан, г. Алматы \\ e-mail: Yes171@bk.ru \\ Взгляд на эффективность системы обучения студентов \\ в Казахстане на основе международного опыта
}

\begin{abstract}
Цельстатьи-анализ изменений системы высшего и технического образования Казахстана за 30 лет независимости, продемонстрировать современные трансформационные процессы, связанные с соответствием результатов обучения компетенциям и Национальной рамке квалификаций республики. Были определены цели установления уровня образования в рамках компетентного подхода. В качестве методов использовались анализ научной митературы и образовательных Аокументов, анкетирование и опытная работа. На основе анализа выявлены проблемы с качеством образования, необходимость продвижения концепции результатов обучения с точки зрения приверженности компетентности. На данном этапе развития образовательной системы очевиАно, что концепция результатов обучения с точки зрения приверженности компетентности имеет решающее значение. Рекомендации Республики Казахстан по обеспечению качества образования сформулированы в контексте компетентного подхода.

В рамках исследования проведен опрос студентов на базе Казахского национального педагогического университета им. Абая. В опросе приняло участие 100 респондентов. Опрос показал - что $88 \%$ респондентов считают, что систему обучения необходимо совершенствовать в соответствии с современными стандартами. Рекомендуется совершенствование и усиление Национальной сети квалификаций в соответствии с принципами Европейской сети квалификаций.

Кмючевые слова: компетенции, результаты обучения, техническое образование, Национальная сеть квалификаций.
\end{abstract}

\section{Introduction}

Details and summaries on Kazakhstan's higher and technical education.

The right to education is guaranteed by the state, according to the Constitution of the Republic of Kazakhstan, through the development of the educational system, the strengthening of the legal framework for its operation, and the creation of the requisite socioeconomic conditions for education. The school system's main goals are to create the necessary conditions for high-quality education aimed at the formation, advancement, and professional growth of individuals based on national and universal human values and scientific and technological achievements; development of a person's creative, spiritual, and physical abilities, formation of solid ethical principles and a healthy lifestyle; and intellectual development. (Black \& Wiliam, 1998)

The Republic of Kazakhstan's education system is divided into four tiers: pre-university education, university education, post-graduate studies, and higher education.

1) Early childhood education;

2) primary school education;

3) higher education for all;

4) secondary education (general secondary education, technical and vocational education);

5) post-secondary education;

6) Education above a bachelor's degree.
A standard national exam in the form of a graduate exam must be taken and passed to gain admission to a higher educational institution (HEI). Student has earned a credential and/or an academic degree since completing technical higher education.

Master's degrees are the highest level of education. A master's degree requires the completion of a bachelor's and/or master's degree, as well as the defense of a thesis. Honorary degrees are awarded to Master's program graduates and others who successfully defend their thesis.

Usually, a doctoral program refers to postgraduate education. Individuals with a master's degree or who have passed a professional doctorate examination can receive the title of Doctor in Philosophy or Doctor of the Profile. Doctor of Philosophy (PhD) or Doctor of the Professions degrees are awarded to them (DP).

The relation between skills development and higher education is discussed in this essay (HE)

On a general education level, technical and professional education is provided through vocational schools, junior colleges, and universities. Citizens with a primary, secondary, post-secondary, vocational, technical, or general education may enroll in higher education (Figure 1). Furthermore, we must point out that in the informal education sector, more than 20,000 people undergo training and retraining each year without an increase in educational standards. 


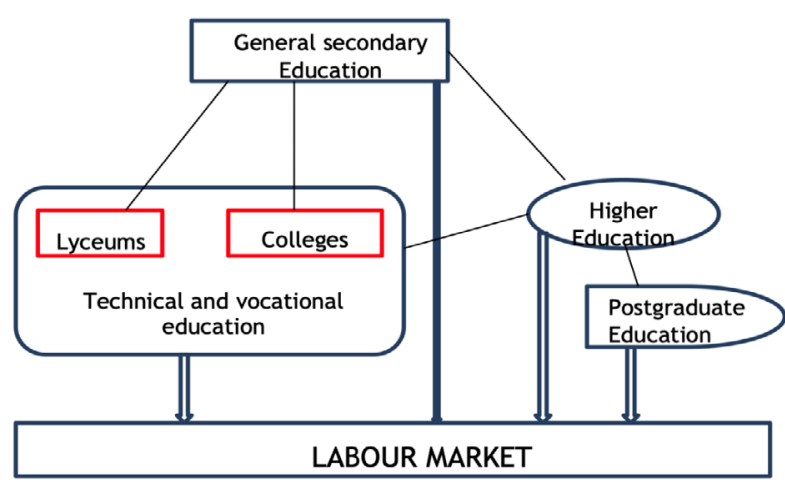

Figure 1 - Ways to enter the labor market for citizens

\section{Methods}

It is recognized that we must deal with poorly structured and non-numerical information in general during educational research, which cannot always be reduced to a form appropriate for applying methods of exact sciences, such as mathematical statistics methods. Pedagogical quantification - the use of quantitative methods in pedagogy - has become a popular and growing practice. However, general experimental testing methods such as systematic approaches, action approaches, simulation, mental experiment, and others are used to design pedagogical problems. We believe qualitative analysis is needed for our research.

One of the most popular types of scientific methods is theoretical methodology. Pedagogy is a set of approaches for assessing pedagogical actions that are based on general systems theory. (Gipps, 1999), and so on. It is assumed that if an external control action is applied into the system with the desired effect, the desired result will occur as a direct result. (Hattie \& Timperley, 2007) The use of a qualitative approach for system evaluation provides the most precise information about the system's status and performance outcomes. (Robinson, 1972).

Qualimetry is a science that studies the measurement and evaluation of quality in all artifacts and processes. (Chen, 1994) It is divided into three categories: general, special, and subject qualimetry.

The literature review focused on well-known works on the topic in question. The accumulation/ buildup process occurs in evolution for the development of information and the creation of new knowledge.

The processing of knowledge occurs over time rather than as a result of a single lesson.

The most important methods of study are a number of laboratory experiments. (MacAulay, 2013)
We used a number of quantitative methods to measure the effectiveness of higher education.

1. Evidence-gathering questionnaires;

2. Gathering evidence (digital data, metrics, and financial indicators);

3. Interrogating experts and prospective employers;

4. The results of official ratings, board reviews, certifications, and accreditations.

\section{Results}

Competence-Based Performance and Thinking Results

The aim of multiple learning outputs methods is investigated in this paper.

The graduate's qualification requirements were incorporated into an approved postgraduate qualification profile issued by an educational authority (Ministry). "Qualification" is described in dictionaries as "the requisite expertise, training, skills, and experiences for a particular job or profession." The instructor has verified that the student has the ability to perform specific occupational tasks as well as the necessary experience to meet state education requirements. The Higher Educational Institution verified the degree, and the Higher Educational Institution validates the qualification in the educational field. As a result, a graduate gained valuable experience working in the real world. Performance management is the standard for assessing professional qualities. In the case of school-based certification, the educational system meets the requirements of the labor market. As a result, vital knowledge and abilities for human life and action cannot be developed. (Papanastasiou, 1999)

However, it's worth noting that the attention moved from recording the instructional process to monitoring academic outcomes. The modern educational model emphasizes the application of curriculum design principles, with educational outcomes serving as valuable learning tools. If the planning and implementation of the educational process (education, teaching, and technique) were previously performance indicators of university educational action, this approach now includes educational outcomes, such as student developed knowledge, skills, and skill, formal and informal modes of learning, and self-study. As a result, assessing student educational performance in education necessitates determining maturity rather than knowledge, skills, or capacity. Linking the transfer of competencies to a competence-based approach in the educational process is critical in order to direct higher education to- 
ward meeting the needs of the labor market. (Peters, 2014)

\section{National Qualification Network}

According to the international practice study, the basis of credential networks is direct relationships between labor sector health standards and employee fitness assessment. The fitness to create this educational program is determined during the process of mastering an educational program in an educational institution (if the program is based on results criteria), during work operations, during selfstudy, and also by the use of advanced technology opportunities.

As a result, it's critical that teachers encourage casual and spontaneous learning. Semi-structured learning is learning when performing an activity in a setting that includes a teaching feature. Learning that occurs in the sense of human daily life, such as at work, school, or in a family, is referred to as random learning.

Many countries are adopting guidelines and institutional mechanisms for identifying informal and non-formal learning outcomes that have been fully compliant with the tasks of implementing lifelong learning strategies, which is a fundamental growth strategy almost everywhere in the world. The EU Framework for Education and Training is used by EU countries to carry out this strategy. In this way, the credential network lays the groundwork for the systematization and identification of learning results, as well as the improvement of qualification standards, availability, interconnection, and acceptance both nationally and internationally. (Harvard, 2021)

According to international standards, learning outcomes are defined in the labor sector, i.e., by employers, and are used to shape qualifications in the majority of countries. "The learning outcomes describe what knowledge and abilities are expected of the pupil following satisfactory completion of the educational process," according to educational institutions. "The teaching strategies describe what knowledge and abilities are required of the pupil following satisfactory completion of the educational process," according to educational institutions.

As a result, technical education systems are focused on performance-based expectations, which assume three different types of standards:

- occupational requirements (tasks an individual must perform and the minimum skills required to complete them);

- credential criteria (describes the specifications for granting a qualification);
- identifying and clarifying educational standards, a descriptive overview of the schooling outcomes required for qualification, tasks and learning modes, and a learning continuum (in an educational institution, at an enterprise etc.).

The Republic of Kazakhstan's higher education sector has adopted vocational education educational norms that are based on learning outcomes. With these considerations in mind, it is preferable to follow international practice. In most European countries, labor unions (corporations, unions, etc.) set the occupational standards that serve as the foundation for setting job standards. Although many countries have previously developed guidelines, they are no longer carried out separately. The "results-oriented theory of education" refutation does not apply in this case. This is because employers' representatives participate actively in the preparation of learning outcomes descriptions (which are necessary for labor competences) and the criteria for evaluating them. Implementing occupational and technical standards necessitates the development of a single approach that can be used in several countries. (Kussainov, 2021)

This experience is often used in Kazakhstan to standardize curriculum. Members of the educational sphere, with the assistance of labor sphere representatives, settle on an individual, topic, occupational activity functions; form the necessary competences, and so on, who is an authority of the second party, and then they work out content of education, qualifications to graduate degree level, and other issues. The importance of integration is explored, as well as how it contributes to educational and professional norms. However, the Republic of Kazakhstan's state-funded education and science-creation programs aim to increase the share of VET specialties with educational programs developed under vocational requirements to 58 percent in 2016, and 45 percent in 2019. (Kussainov, 2021)

\section{Employer's requirements to qualifications}

In order to meet an employer's qualification requirements, a student must already have theoretical and scientific knowledge in the field. Many of the requisite qualitative requirements are set up in such a way that the other so-called abilities become necessary. The history of human capital growth is critical to the development of human and social capital. The cognitive domain focuses on "logical thinking, ability to concentrate energy, creative work," the affection domain focuses on "readiness to learn, ability 
to study," and social competence focuses on "touch, ability to plan, teamwork, and language skills," and the social competence domain focuses on "contact, ability to prepare, teamwork, and language skills."

A practical experience of graduate activity is often interpreted as a certain amount of newly acquired knowledge and skills, and most often as an indicator of personal initiative, participation in the economy, and specific labor fields. The partnership between professional and non-professional vital goals, as well as a person's career plans and teambuilding skills.

It is simpler to award qualification and a proper degree based on the results of a learning assessment. This has an impact on the learning process, which contributes to the use of special assessment strategies. The evaluation results determine a student's successes in the course of acquiring knowledge and functional skills, which are attained and demonstrated after completion of the entire learning curriculum or a single module of the educational program, allowing for the measurement of specific individual educational achievements. In this regard, objective evaluation criteria and learning achievement indices will be developed, as well as ways and means for assessing learning outcomes and a single framework for assessing performance.

There is a list of learning outcomes that are now available:

- making a detailed list of the priorities and characteristics of students' work;

- making credentials more transparent.

Maintaining a similar curriculum design style for different modes of study; ensuring clarity between labor market requirements and program content and evaluation.

According to Western scholars, articulating educational results in the language of competencies is a way to broaden academic and technological recognition and flexibility, as well as increase the comparability and compatibility of diplomas and qualifications, but the exact significance of this term is unknown. After reading through all of the various concepts for learning results, it's clear that phrases like "measured success," "demonstration," and "to do" exist. The expert's opinion reflects the Bologna Declaration's current definition of the Bologna Process: it is a method of modeling learning outcomes and providing them as norms as higher education quality standards. The competencies to be learned in each curriculum and the total competencies needed in the program are the outcomes. This summary serves as the basis for our investigation.

\section{Quality analysis}

In 2013, 84.2 percent of intramural graduates of technical schools and colleges educated under state order were employed, with 70.5 percent employed, 9.4 percent continuing their education at universities and colleges, and $15.8 \%$ unemployed. Working university graduates accounted for $79.9 \%$ of the total in $2013,82.6$ percent in $2009,84.63$ percent in $2012,81.5$ percent in 2008 , and 51.6 percent in 2009. Technical and vocational education graduates accounted for 84.63 percent in 2012, lyceums accounted for 81.5 percent in 2008 , and colleges accounted for 51.6 percent in 2009. (National Report, 2021)

Low reputation of vocational education and training (VET), lack of legislative rules for employers' vocational qualification testing, lack of VET program standardized measurement techniques, unattractiveness of higher and postgraduate education for foreign nationals, and so on are all listed in Kazakhstan's 2016 State Job Program for vocational education and science creation. Just 83 percent of pre-service vocational education and training graduates passed their certification exam on the first attempt in 2013. Last year (2007-2013), 13.4\% of all students were exempt from the VET system, with one-third of them being underachievers. In the years 2007-2010, 12.8 percent of students were disqualified from higher educational institutions, 18.6 percent for underachievement, and 9.5 percent for low performance ratings. (National Report, 2021)

"The teaching staff of universities confirms that the standard of students admitted to universities has been decreasing," writes A.Kusainov, President of Kazakhstan's Academy of Pedagogical Sciences (2013). These school graduates will not be able to get a quality education in the country's universities." (Kussainov, 2021)

School programs tend to educate professionals based on their own perspectives, but this does not adequately prepare students for the job market. Some heads are unaware of the skills required for their employees to succeed. Theory trumps practice when it comes to studying. The benefits of informal education are secondary to those obtained by formal education. The problem was upgraded due to the introduction of a Lisbon Strategy as well as an Education and Training Program.

As a result, the country's vocational education sector faces the following challenges: a weak material-technical foundation; an ineffective quality assurance system; a weak connection between the education and training system and the labor mar- 
ket; a lack of knowledge of skills system strengths; insufficient coverage of independent training and evaluation of qualifications based on competencies; and a lack of resources. (Kussainov, 2021)

Сколько человек приняло участие в опросе? Где проводился опрос?

In 2020, we conducted interviews with 65 employers of the students who graduated Abai KazNPU in Almaty city, to reveal about their current ambitions for our graduates, not just in terms of studying Kazakhstan but also in terms of jobs. After pondering answers to the question, «What professional skills and personal values do graduates employed by your company lack?» it was discovered that graduates lacked theoretical knowledge and practical experience (Figure 2). Low academic enthusiasm is at the heart of the issue, according to a survey of Abay University students, they are motivated to work hard in 23.66 percent and 31.68 percent of cases, when the schedule of study is self-selected and when they will pass the course without the finals.

According to this study on worker productivity, a substantial number of teachers have extensive knowledge in a specific field and have extensive classroom experience ( 74.4 percent of teachers have a higher than average or equal to the average indicators). The problem necessitates less involvement and initiative in computer and communication technology mastery than is typical.

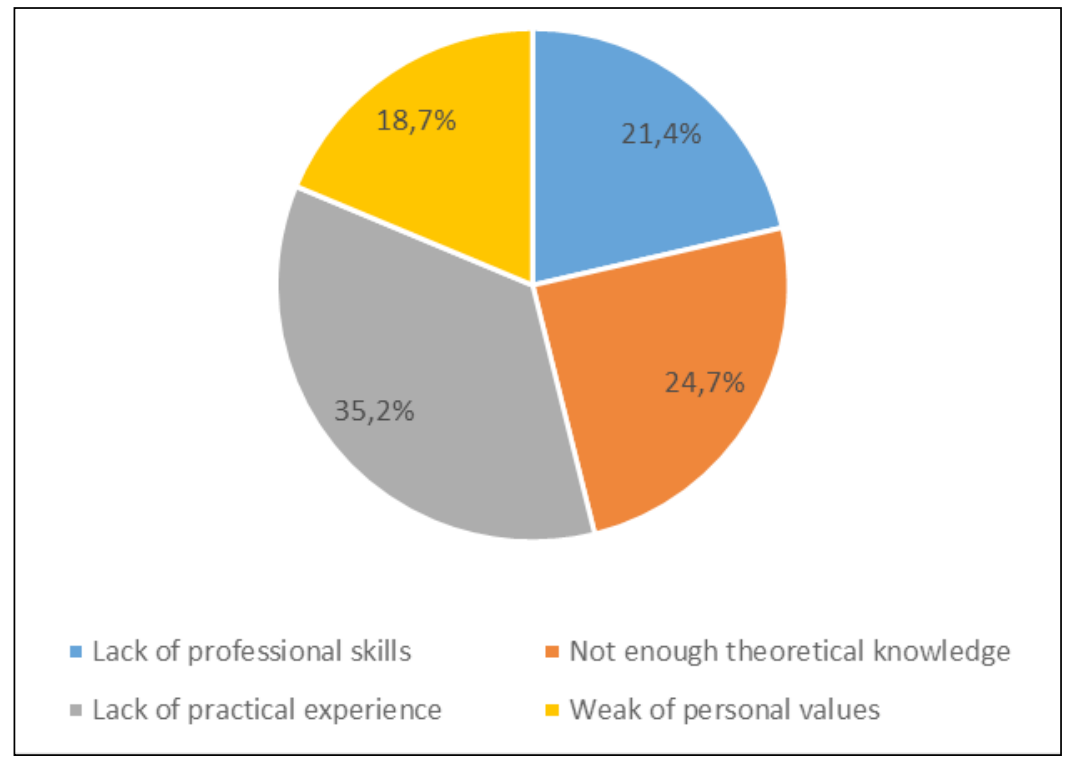

Figure 2 - Professional knowledge and personal qualities of graduates

According to a study of educational system assessment instruments, it receives a 4 out of 5 rating on average. The lowest point in the educational process is the teaching and manufacturing facilities (technical unit, personal computer, etc.).

According to the results of the report, only 50.8 percent of teachers have a complex consolidation and practical execution of the experience in imitation (planned games, role plays), and teachers at certain universities do not prepare or form together with students in practice.

The technologies of intellectual discourse ("debate") (use coefficient: -1.79), critical thought growth (1.82), and critical thinking creation (2.2) are the most commonly used technologies in education by teachers under 30 years old. Teachers prior to and after the age of 55 years used inadequate teaching strategies, and teachers over 55 years used computer-based support systems insufficiently $(0.59)$.

The results of the pedagogical experience data were almost identical to those of the previous report on the age of university teaching staff. It's worth remembering that even more experienced teachers have trouble using computers and other forms of information and communication technology. (5.45) Similar results were discovered at Abay University.

In Figure 3, the University's operations are summarized as a table in terms of customers, staff, culture, and primary performance indicators. 


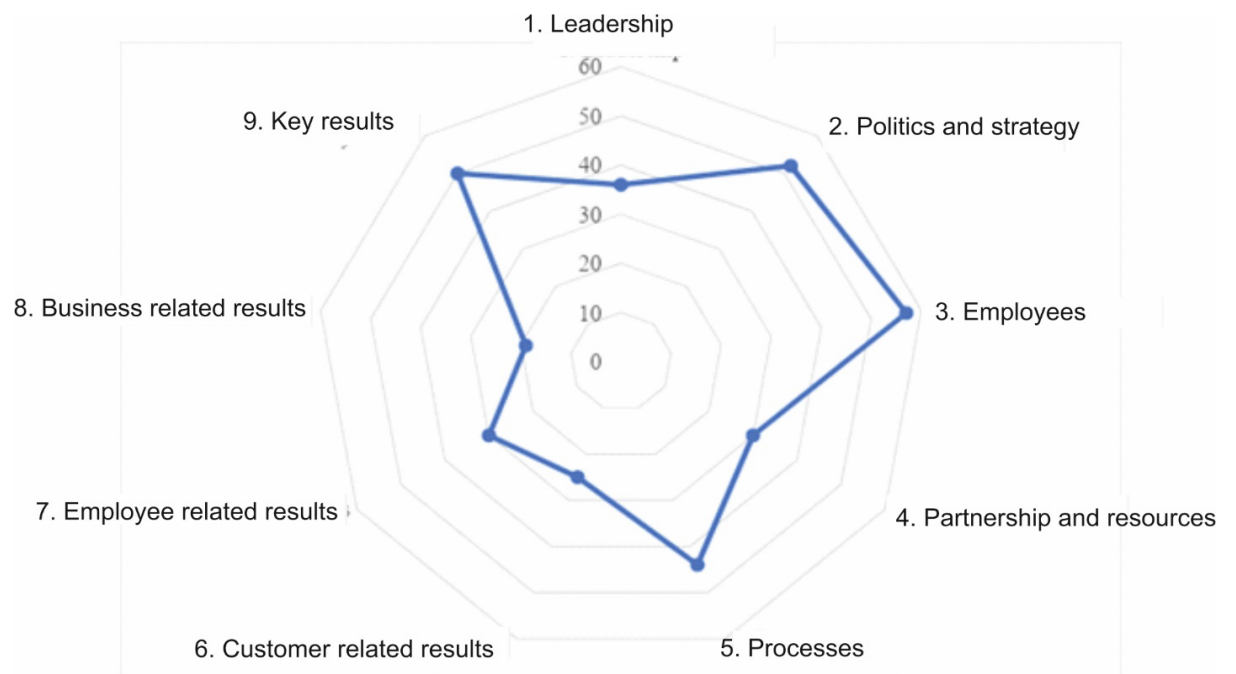

Figure 3 - Students' activity results

Politics and strategy placed at 50

Employees related results at 30 and etc.

\section{Discussion}

The educational system fails to meet the needs of employers in terms of what is expected of a graduate's certification.

According to the Director of the Ministry of Education and Science's Technical and Vocational Education Department, the implementation of a national qualification network should be the primary goal of educational development. G. Kobenova, the Minister of Education and Research's counselor, believes that workplace regulations are critical in eliminating occupational safety and health risks. The National Research and Methodological Center for the Advancement of Professional and Vocational Training and Certification's director calls for occupational standards to be established quickly.

Global Employment Trends for Youth (2020) cites a lack of social support as one of the factors that prevent graduates from entering the workforce. This, however, will cause a problem for your business. Currently, the organization uses a structured preparation process. These individuals are taught how to retrain at their places of employment. Most graduates find it difficult to use critical thinking and teamwork skills to complete the job.

Considerations must be taken into account that one of the factors that ensures the success and effectiveness of school education in Central Asia is the security of national objectives, own traditional cul- ture, traditional values, and upbringing spiritually rich personality," states the professor. (Kussainov, 2021) This should be our key focus as both employees must be employed in active positions. We must restore the traditional Kazakh national school's fundamental ideas and values, which date back to ancient times.

Many people believe that national-focused education will be the cornerstone of a comprehensive education reform in the country.

\section{Conclusion}

We agree that a National Qualifications Network is a significant contributor to the growth of these issues.

Nonetheless, it is essential to revise the Republic of Kazakhstan's NQN and cancel the certificates that are based on it. In addition, the methods for defining occupational skills for specific time periods were modified. We have extensive experience in developing occupational criteria for higher education and can therefore contribute to the advancement of this sector. The higher education system must integrate knowledge gained from the modular education and training system's implementation.

The exchange of information about quality assurance by qualification process should be prioritized. In order to operate properly in the vocational education system, certification centers are necessary. 


\section{References}

Black, P., \& Wiliam, D. (1998). Assessment and Classroom Learning. Assessment In Education: Principles, Policy \& Practice, 5(1), pp. 7-74. https://doi.org/10.1080/0969595980050102

Chen, H. (1994). A Panel on Theory-driven Evaluation and Evaluation Theories. Evaluation Practice, 15(1), 73-74. https://doi. org/10.1177/109821409401500107

Gipps, C. (1999). Socio-Cultural Aspects of Assessment. Review Of Research In Education, 24, 355. https://doi. org/10.2307/1167274

Global Employment Trends for Youth 2020: Technology and the future of jobs. (2020, March 9). International Labour Organization. https://www.ilo.org/global/publications/books/WCMS 737648/lang--en/index.htm

Harvard. (2021). Evaluation Theory or What Are Evaluation Methods for? / Evaluation Methodology / Issue Archive / The Evaluation Exchange / Evaluation / HFRP - Harvard Family Research Project. Archive.globalfrp.org. Retrieved 19 March 2021, from https://archive.globalfrp.org/evaluation/the-evaluation-exchange/issue-archive/evaluation-methodology/evaluation-theory-orwhat-are-evaluation-methods-for.

Hattie, J., \& Timperley, H. (2007). The Power of Feedback. Review Of Educational Research, 77(1), 81-112. https://doi. org/10.3102/003465430298487

Kussainov, A. (2021). Kussainov Askarbek | National Institute of Education (NIE), Singapore. Nie.edu.sg. Retrieved 19 March 2021, from https://www.nie.edu.sg/research/cieclopedia-org/cieclopedia-org-a-to-z-listing/kussainov-askarbek.

MacAulay, M. (2013). Who I Am and Who We Are and Who We Are: How Secondary Organization Membership Moderates the Outcomes of an Identity Comparison Gap with a Primary Organization. SSRN Electronic Journal. https://doi.org/10.2139/ ssrn. 2346546

National Report. (2021). National Report | Информационно-Аналитический центр. Iac.kz. Retrieved 19 March 2021, from $\mathrm{http}: / /$ iac.kz/en/project/nacionalnyy-doklad. (in Russian)

Papanastasiou, E. (1999). Teacher Evaluation. Distributed by ERIC Clearinghouse.

Peters, R. (2014). Promoting the use of higher level cognitive processes in a quantitative analysis course. Teaching Public Administration, 32(1), pp. 39-54. https://doi.org/10.1177/0144739413516482

Robinson, S. (1972). Theories of Economic Growth and Development: Methodology and Content. Economic Development And Cultural Change, 21(1), pp. 54-67. https://doi.org/10.1086/450607

\section{References}

1 Black, P. Assessment In Education: Principles, Policy \& Practice / P. Black, D. Wiliam // Assessment and Classroom Learning. - 1998. - Vol. 1, № 5. - P. 7-74.

2 Chen, H. A Panel on Theory-driven Evaluation and Evaluation Theories / H. 1. Chen // Evaluation Practice. - 1994. - Vol. 15, № 1. - P. 73-74.

3 Gipps, C. Socio-Cultural Aspects of Assessment / C. Gipps // Review of Research in Education. - 1999. - Vol. 24. - P. 355.

4 Mel, M. Evaluation Theory or What Are Evaluation Methods for? / M. Mel // The evaluation exchange. - 2005. - Vol. 11, № 2 .

5 Hattie, J. The Power of Feedback / J. Hattie, H. Timperley // Review of Educational Research. - 2007. - Vol. 77, № 1. - P. 81-112.

6 Kussainov, A. National Institute of Education / A. Kussainov // National Institute of Education. - 2021.

7 MacAulay, M. Who I Am and Who We Are and Who We Are: How Secondary Organization Membership Moderates the Outcomes of an Identity Comparison Gap with a Primary Organization / M. MacAulay // Electronic Journal. - 2013.

8 Iac.kz., Информационно-Аналитический центр / Национальный доклад - 2021.

9 Papanastasiou, E. Teacher Evaluation / Papanastasiou, E. // Distributed by ERIC Clearinghouse - 2014.

10 Peters, R, Promoting the use of higher-level cognitive processes in a quantitative analysis course // Public Administration. 2014 - Vol. 32, №1.

11 Robinson, S., Theories of Economic Growth and Development: Methodology and Content. // Economic Development and Cultural Change. - 1972. - Vol. 21, № 1. - P. 54-67.

12 Global Employment Trends for Youth 2020: Technology and the future of jobs. (2020, March 9). International Labour Organization. https://www.ilo.org/global/publications/books/WCMS_737648/lang--en/index.htm 


\section{5 - бөлім \\ БІЛІМ БЕРУ \\ МЕНЕДЖМЕНТІ \\ Section 5 \\ MANAGEMENT \\ OF EDUCATION \\ Раздел 5 \\ МЕНЕДЖМЕНТ \\ ОБРАЗОВАНИЯ}

